\title{
Shelf life of essential oil of Acantholippia deserticola (Phil. ex F. Phil.) Moldenke and its acaricidal effect on two-spotted mite [Tetranychus urticae Koch (Acari: Tetranychidae)] under laboratory conditions
}

\author{
Vida de anaquel del aceite esencial de Acantholippia deserticola (Phil. ex F. Phil.) \\ Moldenke y su efecto acaricida sobre la arañita bimaculada[Tetranychus urticae \\ Koch (Acari: Tetranychidae)] bajo condiciones de laboratorio
}

Gary Hernández Pinto ${ }^{1}$, Víctor Tello Mercado1,2,*, Tommy Rioja Soto ${ }^{1,2}$

\begin{abstract}
The acaricidal effect of two formulations of essential oil of "rika-rika" [Acantholippia deserticola Moldenke (Verbenaceae)] of 3 and 6 years of shelf life were evaluated on females of two-spotted spider mite [Tetranychus urticae (Acari: Tetranychidae)] registering the repellency and effects on the oviposition. The bean leaf discs [Phaseolus vulgaris Linneo (Fabaceae)] were covered with the formulation using the immersion technique under laboratory conditions $\left(23.31 \pm 2.82{ }^{\circ} \mathrm{C}, 49.70 \pm 1.42 \% \mathrm{RH}\right.$ and $12: 12$ L:D photoperiod). The mortality of T. urticae was evaluated at 24, 48 and 72 hours post-application. The variables evaluated were: percentage of mortality by residual contact, percentage of repellency and number of eggs laid. Only the formulation at $1 \%(\mathrm{v} / \mathrm{v})$ with 3 years shelf life reached a mortality of $50 \%$ after 24 hours of evaluation. The concentrations at $0.3 \%$ and $0.7 \%$ (v/v) with 3 years shelf life reached this value after 72 hours. None of the concentrations with 6 years shelf life reached values above $50 \%$ of mortality. A maximum mortality of $85.71 \%$ was registered in the concentration at $1 \%(\mathrm{v} / \mathrm{v})$ with 3-year shelf life. The 3 -year shelf life formulation showed repellent activity for the three periods evaluated (24, 48 and 72 hours), with values above $90 \%$ after 72 hours post-application. The ovisposture test revealed that the concentrations of 3 years shelf life had an inhibitory effect on the oviposition of the two-spotted spider. These results suggest a considerable acaricidal activity of the essential oil of A. deserticola with a 3-year shelf life on adult females of T. urticae.
\end{abstract}

Keywords: Formulation, repellency, oviposition.

\section{RESUMEN}

El efecto acaricida de dos formulaciones del aceite esencial de Acantholippia deserticola Moldenke (Verbenaceae)("rika-rika) de 3 y 6 años de vida de anaquel fueron evaluaron sobre hembras de Tetranychus urticae (Acari: Tetranychidae) (arañita bimaculada) registrando la repelencia y los efectos sobre la oviposición. Los discos de hojas de poroto [Phaseolus vulgaris Linneo (Fabaceae)] fueron cubiertos con la formulación utilizando la técnica de inmersión en condiciones de laboratorio $\left(23,31 \pm 2,8{ }^{\circ} \mathrm{C}, 49,70 \pm 1,42 \%\right.$ de humedad relativa y fotoperíodo de 12:12 luz: oscuridad). Se evaluó la mortalidad de T. urticae a las 24, 48 y 72 horas después de la aplicación. Las variables evaluadas fueron: porcentaje de mortalidad por contacto residual, porcentaje de repelencia y número de huevos puestos. Sólo la formulación al $1 \%(v / v)$ con una vida útil de 3 años alcanzó una mortalidad del $50 \%$ a las 24 horas de la evaluación. Las concentraciones al 0,3\% y 0,7\% (v/v) con 3 años de vida de anaquel alcanzaron este valor a las 72 horas. Ninguna de las concentraciones con una vida útil de 6 años alcanzó valores superiores al 50\% de mortalidad. Se produjo una mortalidad máxima del 85,71\% por la concentración al $1 \%(v / v)$ con una formulación de vida útil de 3 años. La formulación de vida útil de 3 años mostró actividad repelente para los tres períodos evaluados (24, 48 y 72 horas), con valores superiores al 90\% a las 72 horas después de la aplicación. La prueba de ovispostura reveló que las concentraciones de vida de anaquel de 3 años tuvieron un efecto inhibidor sobre la oviposición de la arañita bimaculada. Estos resultados sugieren una considerable actividad acaricida del aceite esencial de A. deserticola sobre hembras adultas de T. urticae, con una vida de anaquel de 3 años.

Palabras claves: Formulación, repelencia, oviposición.

$1 \quad$ Facultad de Recursos Naturales Renovables, Universidad Arturo Prat. Avenida Arturo Prat 2120, Iquique, Chile.

2 Programa de Doctorado en Agricultura para ambientes Áridos-Desérticos. Universidad Arturo Prat. Iquique, Chile.

* Autor para correspondencia: vetello@unap.cl

Fecha de Recepción: 18 de Abril, 2018.

Fecha de Aceptación: 22 de Noviembre, 2019. 


\section{Introduction}

The mites of the Tetranichydae family correspond to important pests for many crops. One of the most economically important species is Tetranychus urticae Koch, 1836 (Acari: Tetranychidae), a polyphagous species that attacks more than 1,000 plant species (Ximénez-Embún et al., 2017).

The carmine form of the spider mite Tetranychus urticae Koch (Acari: Tetranychidae), formally known as Tetranychus cinnabarinus (Boisduval) (Auger et al., 2013), is one of the most important pests of crops and ornamental plants worldwide.

In Chile, the two-spotted mite is widely distributed and its hosts plant are melon (Cucumis melo (Linnaeus)), bean (Phaseolus vulgaris (Linnaeus)), alfalfa (Medicago sativa (Linnaeus)), peach (Prunus persica (Linnaeus) Batsch), cherry tree (Prunus cerasus (Linnaeus)), strawberry (Fragaria $x$ ananassa (Duchesne)) and carnation (Dianthus caryophyllus (Linnaeus)) (Klein and Waterhouse, 2000).

Tetranychus urticae are located on the underside of the leaves, increasing their population in warm seasons. Precisely, the environmental conditions of northern Chile, of dryness and heat are very favorable for the development of this phytophagous mite (Peralta and Tello, 2011).

The control of $T$. urticae in ornamentals is exclusively with agrochemicals, but the main problem generated with this control technique is a rapid resistance due to their high fertility and fecundity, inbreeding, parthenogenetic reproduction (pseudo-arrhenotoky) and a short life cycle that produces many generations per year (Lu et al., 2017).

The most used chemicals worldwide are fenazaquin, chlorpyrifos, abamectin and last generation acaricides such as spirodiclofen belonging to the new family of spirocyclic tetronic acids, ketoenoles (Demaeght et al., 2013).

The indiscriminate use of conventional pesticides, mainly of broad spectrum, has caused serious health problems for human and imbalance in the agroecosystem. The consequences of these chemical applitations are the development of pest resistance, environmental pollution, outbreaks of new pests, elimination of beneficial insects, increasing chemical accumulation in the trophic chain and intoxication of workers and consumers (Darçın and Darçın, 2017). This problem has increased the interest of farmers and researchers for the search of new chemical control alternatives such botanical extracts (Jallow et al., 2017).

Plants have developed different defense strategies against herbivorous, including chemical direct defense mechanisms producing constitutively secondary metabolites such as alkaloids, non protein amino acids, amines, cyanogenic glycosides, glucosinolates, terpenoids, and phenolics (Mithöfer and Boland, 2012). Several studies show the effects of essential oils against mosquitoes, including growth inhibition, larvicide, adulticide, repellents and oviposition detergent effects (Guo et al., 2017).

In northern Chile, there is a large number of plants species that are used by people for heal different diseases, one of those plants is Acantholippia deserticola (Phil. Ex F. Phil) Moldenke commonly known as "rika-rika"; this species grows in arid regions of northern Chile and Bolivia and northeast and south of Argentina in sandy and stony soils between 2,300 and 3,500 meters above sea level (m.a.s.l.) (Morales et al., 2008).

Rojo et al. (2006) registered 22 compounds in A. deserticola oil by gas chromatography/mass spectrometry (GC/MS) representing $99.31 \%$ of the total oil, where the $\beta$ - thujones compound represent $77.9 \%$, whereas $10.5 \%$ corresponds to $\alpha$-thuyones. Sampietro et al. (2016) identified 28 compoundsfrom oil of leaves of $A$. deserticola, with $66.4 \%$ of $\beta$ thujones, but $\alpha$ - thujones was not detected.

The toxicity of both $\alpha$ - and $\beta$ - thujones compound is due to stimulation of the central nervous system by antagonizing the ionotropic receptors of $\gamma$-aminobutyric acid (GABA), which decreases $\mathrm{Cl}$-currents by reducing inhibition; provoking a convulsive effect in mammals and probably their insecticidal/acaricidal activity (Olsen, 2006).

Different studies support the toxic effects of thujones compound present in essential oils of different plant species against a variety of arthropods: toxic and repellents effect of Artemisia sieberi Besser (Asteraceae) oil on the mite Dermanyssus gallinae (De Geer, 1778) (Acari: Dermanyssidae) (Tabari et al., 2017); insecticidal/acaricidal activity of $A$. deserticola oil on Planococcus citri Risso, 1813 (Hemiptera: Pseudococcidae), Aleurothrixus floccosus Maskell, 1896 (Hemiptera: Aleyrodidae), T. urticae and Brevipalpus chilensis Baker, 1949 (Acari: 
Tenuipalpidae) (Benites et al., 2014); acaricidal properties of essential oils of the asteraceae Artemisia absinthium L. and Tanacetum vulgare L. on adults of T. urticae (Chiasson et al., 2001).

Considering the importance of thujones compound from $A$. deserticola as promising acaricide/insecticide molecules, we propose to evaluate the shelf life of a formulation at different concentrations of the essential oil of A. deserticola on the red form of T. urticae under laboratory conditions.

\section{Materials and Methods}

\section{Plants}

The A. deserticola plants were collected in two dates: first collection in July 2011 and second in July 2013. These collections were made in the same area (Colchane, Región de Tarapacá, Chile; $19^{\circ} 16^{\prime} 22.50$ ' $\mathrm{S}$ and $68^{\circ} 37^{\prime} 40.42^{\prime \prime} \mathrm{W}$, about 3,720 m.a.s.l.). Only the aerial part of plant was collected and transferred to a chamber at low temperature in the Natural Products Laboratory of the Faculty of Health Sciences of the Arturo Prat University, Iquique, Chile.

\section{Acarological material}

For testing the shelf life of the essential oil of $A$. deserticola, we worked with $T$. urticae adults. The mites were obtained from a carnation (Dianthus caryophyllus L.) crop, in 'La Tirana' town (Province of Tamarugal, Chile; 20 $21^{\circ} 12.87$ “S and $69^{\circ} 39^{\prime} 12.82^{\prime}$ " $\mathrm{W}$, about 1,006 m.a.s.l.) in January 2016 and reared in laboratories of the Faculty of Natural Resources and Renewable until testing. For its massive reproduction, $P$. vulgaris Linneo var. "Canario" were planted weekly, in polyethylene containers $(15 \times 15 \mathrm{~cm})$.

\section{Oil isolation of Acantholippia deserticola}

The aerial part of plant was dried at room temperature a week approximately. Once dried, the leaves were separated, which were submitted to a hydro-distillation for 3 hours using Clevengertype apparatus. The oil was protected from direct light and maintained at $4{ }^{\circ} \mathrm{C}$ until the moment to make the formulated. The yield of essential oil of A. deserticola was calculated based on the mass from dry plant material.
To determine the weight of plant material and the volume of the essential oil obtained, a standard-sized plant of $A$. deserticola (without roots) was measured, and the shoots were pruned. The leaves were dried at room temperature and weighed on an analytical balance, and then the volume of essential oil was determined according to the methodology described above.

\section{Elaboration of the formulated}

The formulated was prepared according to Zarria et al. (2010), in the Laboratory of the Natural Products Institute of the Faculty of Health Sciences of the Arturo Prat University. $250 \mathrm{~mL}$ of the formulations were prepared for different concentrations $(0.3,0.7$ and $1.0 \% \mathrm{w} / \mathrm{v})$. Two formulations were prepared: one from plants collected in 2011 (shelf-life: 6 years) and other from plants collected in 2014 (shelf-life: 3 years).

\section{Bioassays}

Leaf disks (diameter $=2 \mathrm{~cm}$ ) were cut with a punch. They were immersed for 10 seconds in each concentration (treatment) of the essential oil $(0.3,0.7$ and $1 \% \mathrm{w} / \mathrm{v})$, in $2 \mathrm{~mL}$ of solution for $30 \mathrm{~s}$ and dried at room temperature. Once dry, the leaf discs were placed on wet cotton into a Petri dish $($ diameter $=10 \mathrm{~cm})$. The edges of each leaf disc were covered with a fine line of glue (Point Sticky Glue ${ }^{\circledR}$, Point Chile) to prevent the escape of adult mites. Finally, using a fine brush, 10 adult females were transferred to the surface of each leaf disk. As a negative control, water was used, whereas as a positive control the chemical abamectin $\left(2.4 \times 10^{-5} \mathrm{~g}\right.$ in $2 \mathrm{~mL}$ of the solution). The experimental unit was a leaf disc with 10 individuals and each treatment was repeated 10 times. All the tests were carried out under conditions at $23.31 \pm 2.82{ }^{\circ} \mathrm{C}$ of temperature, $49.70 \pm 1.42 \%$ of $\mathrm{RH}$ and a photoperiod of 12:12 L: D.

\section{Residual contact mortality test on adults of Tetrannychus uticae}

Eggs laid by approximately 50 females during a period of 12 hours were collected in plastic boxes. These boxes were kept in the same conditions until the larvae hatched. This cohort was reared until when the adults of $T$. urticae were obtained. 
Subsequently, groups of 10 adult females were placed on leaf disks previously washed with distilled water and its edges delimited with a fine line of glue (Point StickyGlue ${ }^{\circledR}$ ) to prevent the escape of mites. The experiment was repeated 10 times for each concentration. The mortality of the females of T. urticae was quantified at 24, 48 and $72 \mathrm{~h}$ after the application, registering as dead those individuals without mobility when they were stimulated with a fine brush.

\section{Repellency test}

Bean leaf discs $($ diameter $=2 \mathrm{~cm})$ were used. The discs were cut so that the mid-rib of the leaf was in the middle of the leaf disc. Each disc was submerged only halfway (midrib of the leaf) in the different treatments and allowed to dry at room temperature. Only one concentration corresponding to $0.7 \%(\mathrm{w} / \mathrm{v})$ of the essential oil of A. deserticola was applied. Subsequently, the discs were placed into Petri dishes $($ diameter $=10 \mathrm{~cm})$.

After the application, 10 adult females were placed in the central venation of the leaf disk (choice test). The repellent effect was calculated by the percentage of adults who stayed out of the applied half, in three evaluation periods: 24,48 and $72 \mathrm{~h}$ post-application. A leaf disc with 10 adult females corresponded to an experimental unit.

\section{Effect on oviposition}

For this test, the same methodology applied in the residual contact mortality test was used. Once the treatments were applied, glue was applied to the border of the leaf discs; each of them had a female and a male of T. urticae. Each treatment was repeated 10 times. The same controls were used. The number of eggs laid per female was evaluated up to the third day after application.

\section{Design and statistical analysis}

For all experiments, a completely randomized design was used. Natural mortality was corrected using Abbott's formula (Abbott, 1925). The data of percentages and counts due to not complying with the normality assumption were analyzed through a non-parametric analysis of variance (KruskalWallis), with a level of significance of $\alpha=0.05$. To compare two means, the non-parametric Wilcoxon test and the paired t-test were used, both with a significance of 5\%. The statistical analyzes were performed with the InfoStat program, version 2018.

\section{Results and discussion}

\section{Mortality test}

In the formulated of 3 years shelf life, at 24 , 48 and $72 \mathrm{~h}$ post-application, there were significant differences $(\mathrm{p}<0.0001)$ between the treatments (Table 1). The treatment at $1.0 \%(\mathrm{w} / \mathrm{v})$ concentration was the only one that reached over $50 \%$ mortality after $24 \mathrm{~h}$, compared to the concentrations at 0.3 and $0.7 \%(\mathrm{w} / \mathrm{v})$ that reached this value at $72 \mathrm{~h}$ post-application. Only in the last evaluation, the three concentrations reached mortality percentages statistically equal to the chemical control (98.57\%). The extracts of A. deserticola of 6 years of storage did not show significant differences among treatments at $0.3,0.7$ and $1 \%(\mathrm{w} / \mathrm{v})$. Although the mortality percentages were greater than $72 \mathrm{~h}$ postapplication, they did not exceed $50 \%$.

Comparing the mortality produced between the formulations from 3 and 6 years shelf life at $72 \mathrm{~h}$ post-application (Figure 1), there were significant differences in the concentrations at $0.7 \%(W=$ $143.00, p<0.05)$ and $1 \%(W=86.50, p<0.05)$.

Benites et al. (2014) evaluated the essential oil of A. deserticola on T. urticae, with the lowest concentration at $2 \%(\mathrm{w} / \mathrm{v})$ obtaining a mortality of $10.44 \%$ at $24 \mathrm{~h}$ post-application, and with the highest concentration at $5 \%(\mathrm{w} / \mathrm{v})$ reached a mortality of 82.18\%; whereas, in the present study after $24 \mathrm{~h}$ and a concentration of $0.3 \%(\mathrm{w} / \mathrm{v})$ the formulation of 3 years shelf life reached a mortality of $23.65 \%$.

Chiasson et al. (2001) studied the essential oil of Tanacetum vulgare L. (Asteraceae) on adult of T. urticae, which contained $91.1 \%$ of $\beta$-thujone, using a concentration at $4 \%$ v/v after 48 hours post-application obtained a mortality of $75.6 \%$.

Immaraju (1998) indicated that the storage time of a formula based on the active ingredient azadirachtin showed a stability of 1 year; then, losing between 3-5\% of the content of azadirachtin at room temperature and with low relative humidity. In addition, Jadev et al. (2006) evaluated the systemic and persistent effect of Neem formulations against nematodes of root knots and its shelf life; finding that after 8 months of storage with exposure to direct light the efficiency decreased, thus for 
Table 1. Mortality (\%) of Tetranychus urticae adults by indirect application of different concentrations of the essential oil of Acantholiphia deserticola of 3 and 6 years shelf life.

\begin{tabular}{|c|c|c|c|c|c|c|}
\hline \multirow{3}{*}{ Treatments } & \multicolumn{3}{|c|}{3 years shelf life } & \multicolumn{3}{|c|}{6 years shelf life } \\
\hline & $24 \mathrm{~h}$ & $48 \mathrm{~h}$ & $72 \mathrm{~h}$ & $24 \mathrm{~h}$ & $48 \mathrm{~h}$ & $72 \mathrm{~h}$ \\
\hline & \multicolumn{6}{|c|}{ Average Mortality ${ }^{1}\left( \pm \mathrm{EE}^{2}\right)$} \\
\hline $0.3 \% \mathrm{w} / \mathrm{v}$ & $23.65 \pm 6.18 b c$ & $42.65 \pm 8.92 b$ & $68.00 \pm 9.61 \mathrm{a}$ & $15.52 \pm 3.46 \mathrm{~b}$ & $29.01 \pm 5.26 \mathrm{~b}$ & $43.73 \pm 9.81 \mathrm{~b}$ \\
\hline $0,7 \% \mathrm{w} / \mathrm{v}$ & $17.62 \pm 7.75 c$ & $47.00 \pm 8.66 b$ & $85.00 \pm 6.31 \mathrm{a}$ & $9.15 \pm 3.31 \mathrm{bc}$ & $20.58 \pm 3.22 b$ & $45.44 \pm 9.42 b$ \\
\hline $1 \% \mathrm{w} / \mathrm{v}$ & $54.17 \pm 15.02 \mathrm{ab}$ & $78.57 \pm 10.10 \mathrm{ab}$ & $85.71 \pm 14.29 \mathrm{a}$ & $17.45 \pm 4.76 b$ & $30.42 \pm 8.24 \mathrm{~b}$ & $42.14 \pm 11.38 \mathrm{~b}$ \\
\hline Water & $0.00 \pm 0.00 \mathrm{c}$ & $0.00 \pm 0.00 \mathrm{c}$ & $0.00 \pm 0.00 \mathrm{~b}$ & $0.00 \pm 0.00 \mathrm{c}$ & $0.00 \pm 0.00 \mathrm{c}$ & $0.00 \pm 0.00 \mathrm{c}$ \\
\hline \multirow[t]{2}{*}{ Abamectin } & $86.28 \pm 2.18 \mathrm{a}$ & $94.68 \pm 2.23 \mathrm{a}$ & $98.57 \pm 1.43 \mathrm{a}$ & $86.28 \pm 2.18 \mathrm{a}$ & $93.68 \pm 2.19 \mathrm{a}$ & $98.57 \pm 1.43 \mathrm{a}$ \\
\hline & \multicolumn{6}{|c|}{ ANOVA } \\
\hline KW & 26.83 & 31.43 & 25.03 & 30.62 & 33.74 & 29.53 \\
\hline f.d. ${ }^{3}$ & 4 & 4 & 4 & 4 & 4 & 4 \\
\hline $\mathrm{p}$ & $<0.0001$ & $<0.0001$ & $<0.0001$ & $<0.0001$ & $<0.0001$ & $<0.0001$ \\
\hline
\end{tabular}

1 Means with different letters within each column are statistically different according to the Kruskal-Wallis test $(\mathrm{P}<0.05)$.

2 S.E.: Standard error.

3 f.d.: freedom degrees.

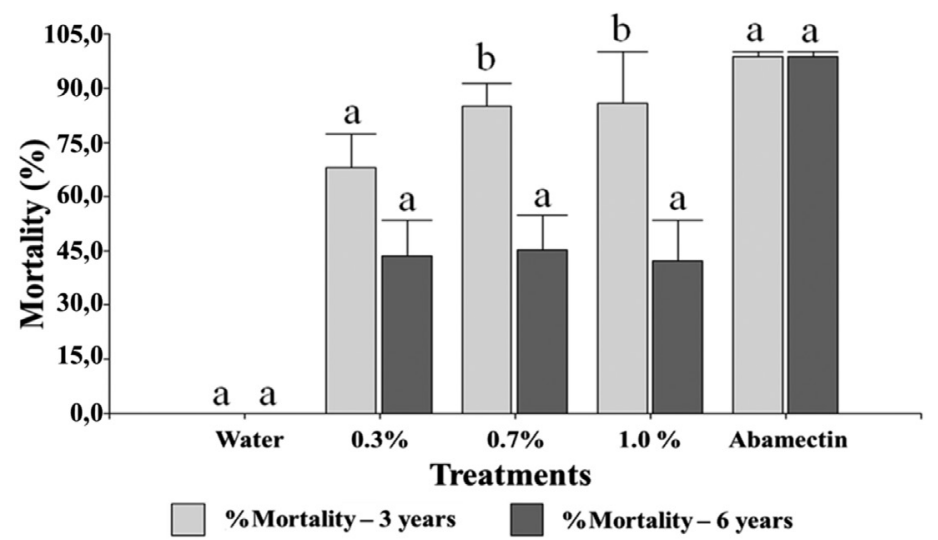

Figure 1. Mortality (\%) of Tetranychus urticae adults by indirect application of different concentrations of the essential oil of Acantholiphia deserticola of 3 and 6 years shelf life. Means with different letters within each evaluation time are statistically different according to the Wilcoxon test $(\mathrm{P}<0.05)$.

increasing its shelf life should be stored in dark with low temperatures or under normal storage conditions (in darkness and at room temperature). In the present study, the incidence of light had no any effect on the microemulsion of the essential oil of $A$. desertciola since the oil was storage in amber bottles completely hermetic and without filtration of light.

Likewise, Balasubramanian et al. (2008) evaluated different forms of storage based on Ayurvedic principles, indicating that the storage time of some biopesticides, according to their physical composition persist between 1 to 3 years. In that regard, we found that the acaricidal properties were maintained in A. deserticola microemulsion with 3 years shelf life, unlike to 6 years shelf life. Therefore, the A. deserticola formulation loses the biological activity after 3 years shelf life.

\section{Repellency test with formulations of 3 years shelf life}

According to Table 2, the control treatment (water) did not show significant differences 
Table 2. Distribution of Tetranychus urticae adults in treated and untreated areas with essential oil of Acantholippia deserticola.

\begin{tabular}{|c|c|c|c|c|c|c|}
\hline \multirow{2}{*}{ Concentration } & \multicolumn{2}{|c|}{$24 \mathrm{~h}$} & \multicolumn{2}{|c|}{$48 \mathrm{~h}$} & \multicolumn{2}{|c|}{$72 \mathrm{~h}$} \\
\hline & Treated area & Untreated area & Treated area & Untreated area & Treated area & Untreated area \\
\hline & \multicolumn{6}{|c|}{$\%\left(\right.$ means $\left.^{1}\right) \pm$ S.E. ${ }^{2}$} \\
\hline Water & $50.00 \pm 3.16 \mathrm{a}$ & $50.00 \pm 3.16 \mathrm{a}$ & $56.00 \pm 5.10 \mathrm{a}$ & $44.00 \pm 5.10 \mathrm{a}$ & $54.00 \pm 6.00 \mathrm{a}$ & $46.00 \pm 6.00 \mathrm{a}$ \\
\hline $0.7 \%$ & $2.00 \pm 2.00 \mathrm{~b}$ & $98.00 \pm 2.00 \mathrm{a}$ & $10.00 \pm 5.48 b$ & $90.00 \pm 5.48 \mathrm{a}$ & $8.00 \pm 3.74 b$ & $92.00 \pm 3.74 \mathrm{a}$ \\
\hline
\end{tabular}

1 Means with different letters within each column are statistically different according to the paired t-Student test $(\mathrm{P}<0.05)$.

2 S.E.: Standard error.

between both treated and untreated areas in the three evaluation periods, discarding the influence of water in the distribution of mites and the mortality due to the humidity by evaporation of water in laboratory.

The results obtained in the concentration at $0.7 \%(\mathrm{w} / \mathrm{v})$ showed significant differences for the three evaluation periods in the distribution of adults on leaf discs, concentrating in untreated area with percentages $\geq 90 \%$ ( $24 \mathrm{~h}: t=24.0, p<0.0001 ; 48$ $\mathrm{h}: t=4.9, p<0.01 ; 72 \mathrm{~h}: t=6.0, p<0.01)$.

Tello et al. (2014) showed that T. urticae presented a repellence percentage of $94 \%$ with extracts of Lampaya medicinalis F. Phil (Verbenaceae) and Baccharis tola Phil. (Asteraceae) at $3 \%$ concentration after $24 \mathrm{~h}$. However, these percentages decreased at $72 \mathrm{~h}$ post-application, with $66 \%$ and $84 \%$ of repellency for the extracts of L. medicinalis and B. tola, respectively. In the present study, the percentage of repellency generated by the essential oil at $0.7 \% \mathrm{w} / \mathrm{v}$ of $A$. deserticola was $98 \%$ after $24 \mathrm{~h}$, and remained above $90 \%$ after $72 \mathrm{~h}$ of exposure.

Harder et al. (2014) conducted a repellency study using extracts of Chenopodium quinoa Willd. (Chenopodiaceae) with $4 \%$ of concentration on T. urticae and exposition during $24 \mathrm{~h}$, they obtained 100\% repellency; in adittion, this percentage of repellency decreased at $76.24 \%$ after $72 \mathrm{~h}$ of exposition. However, the essential oil of $A$. deserticola presented a lower percentage of repellency (98\%), althought remained above $90 \%$ after $72 \mathrm{~h}$ of exposition.

\section{Effect of essential oil on the oviposition of Tetranychus urticae}

There were significant differences between the concentrations evaluated at 24,48 and $72 \mathrm{~h}$ with formulations of 3 and 6 years of storage (Table 3). The concentration at $1 \%(\mathrm{w} / \mathrm{v})$ had the lowest number of eggs after $72 \mathrm{~h}$ of application. The three concentrations of $A$. deserticola did not show significant differences with the chemical control (Abamectin) in different evaluation times.

The formulated of $A$. deserticola with 6 years of storage showed significant differences after 24, 48 and $72 \mathrm{~h}$ of exposition. The treatments of 0.3 and $0.7 \% \mathrm{w} / \mathrm{v}$ did not show significant differences for all evaluations. The concentration at $1 \% \mathrm{w} / \mathrm{v}$ presented the highest average number of eggs. The average of eggs laid by $T$. urticae females exposed to different concentrations of $A$. deserticola microemulsion was lower using formulated with 3 years shelf life, compared to concentrations of 6 years of storage. Likewise, Balasubramanian et al. (2008) indicates that the plant extracts can be stored up to 3 years maintaining the biological activity intact, corroboting the results obtained in the present study, where the highest average of eggs laid by T. urticae females was registered in formulated with 6 years shelf life.

The number of eggs laid was increased with the exposition timein all treatments and formulations, except in the treatment at $1 \% \mathrm{w} / \mathrm{v}$ with 3 years shelf life; seemingly this was caused by the low residual power of these extracts and environmental conditions. The chemical control registered a low number of eggs laid; whereas, the water control showed the highest number of eggs laid.

Comparing the formulated of 3 and 6 years shelf life, there were significant differences in three concentrations evaluated after $72 \mathrm{~h}$ of exposition: $0.3 \%(W=55.00, p<0.001), 0.7 \%(W=$ $55.00, p<0.001)$ and $1.0 \%(W=65.00, p<0.05)$ (Figure 2).

Castiglioni et al. (2002) evaluated aqueous extracts of Meliaceae plants on total oviposition 
Table 3. Number of eggs laid by adult females of Tetranychus urticae exposed to three concentrations of Acantholippia deserticola oil of 3 and 6 years shelf life.

\begin{tabular}{|c|c|c|c|c|c|c|}
\hline \multirow{2}{*}{ Treatment } & \multicolumn{3}{|c|}{3 years shelf life } & \multicolumn{3}{|c|}{6 years shelf life } \\
\hline & $24 \mathrm{~h}$ & $48 \mathrm{~h}$ & $72 \mathrm{~h}$ & $24 \mathrm{~h}$ & $48 \mathrm{~h}$ & $72 \mathrm{~h}$ \\
\hline & \multicolumn{6}{|c|}{$\mathrm{N}^{\circ}$ Eggs after application } \\
\hline $0.3 \% \mathrm{w} / \mathrm{v}$ & $3.30 \pm 1.17 b$ & $3.60 \pm 1.32 b$ & $3.90 \pm 1.44 b$ & $36.78 \pm 7.14 \mathrm{~b}$ & $49.40 \pm 6.71 b$ & $47.30 \pm 7.26 b c$ \\
\hline $0.7 \% \mathrm{w} / \mathrm{v}$ & $2.00 \pm 1.41 \mathrm{~b}$ & $2.20 \pm 1.38 \mathrm{~b}$ & $2.20 \pm 1.38 \mathrm{~b}$ & $30.30 \pm 6.20 \mathrm{~b}$ & $50.70 \pm 10.70 b$ & $58.80 \pm 11.21 \mathrm{~b}$ \\
\hline $1 \% \mathrm{w} / \mathrm{v}$ & $1.00 \pm 0.56 b$ & $1.40 \pm 0.62 b$ & $1.00 \pm 0.56 \mathrm{~b}$ & $7.30 \pm 3.14 \mathrm{c}$ & $14.50 \pm 5.17 \mathrm{c}$ & $17.60 \pm 5.94 \mathrm{~cd}$ \\
\hline Water & $99.00 \pm 5.73 \mathrm{a}$ & $131.00 \pm 12.3 \mathrm{a}$ & $141.40 \pm 15.42 \mathrm{a}$ & $99.00 \pm 5.73 \mathrm{a}$ & $131.00 \pm 12.30 \mathrm{a}$ & $141.40 \pm 15.42 \mathrm{a}$ \\
\hline \multirow[t]{2}{*}{ Abamectin } & $0.70 \pm 0.26 b$ & $0.90 \pm 0.23 b$ & $0.90 \pm 0.23 b$ & $0.70 \pm 0.26 \mathrm{c}$ & $0.90 \pm 0.23 \mathrm{c}$ & $0.90 \pm 0.23 \mathrm{~d}$ \\
\hline & \multicolumn{6}{|c|}{ ANOVA } \\
\hline K.W. & 27.26 & 26.29 & 27.20 & 39.73 & 39.73 & 39.54 \\
\hline f.d. ${ }^{3}$ & 4 & 4 & 4 & 4 & 4 & 4 \\
\hline $\mathrm{p}$ & $<0.0001$ & $<0.0001$ & $<0.0001$ & $<0.0001$ & $<0.0001$ & $<0.0001$ \\
\hline
\end{tabular}

1 Means with different letters within each column are statistically different according to the Kruskal-Wallis test $(\mathrm{P}<0.05)$.

2 S.E.: Standard error.

3 f.d.: freedom degrees.

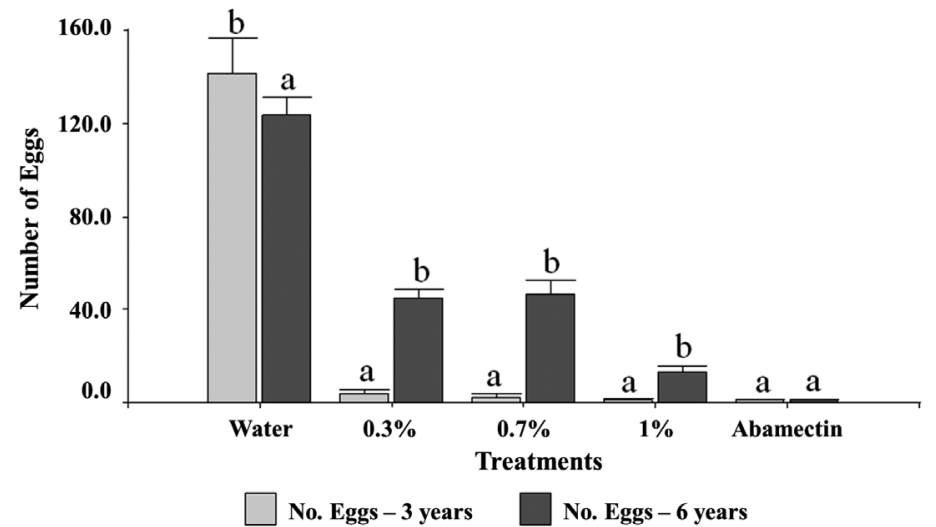

Figure 2. Number of eggs laid by Tetranychus urticae females treated by indirect application of different concentrations of the essential oil of Acantholiphia deserticola of 3 and 6 years shelf life. Means with different letters within each evaluation time are statistically different according to the Wilcoxon test $(\mathrm{P}<0.05)$.

of eggs laid by T. urticae, registering 900 eggs laid by females treated with extracts of Trichilia pallida Sw. (Meliaceae) shoots, and between 600-700 eggs laid by females treated with leaves and seeds of Neem at $5 \%$. In that regard, our results were lower using $A$. deserticola extracts of 3 years shelf life, in comparison to Castiglioni et al. (2002); it seems the relative humidity would have influence since in this study (58\%) was lower than that Castiglioni et al. (2002) (98\%). Finally, it should be mentioned that increasing the concentration of $A$. deserticola extracts, the number of eggs laid decreases.

\section{Conclusions}

Only the essential oil of $A$. deserticola of 3 years shelf life shows acaricidal activity on adult females of T. urticae, and reducing the eggs laid considerably.

The A. deserticola extracts of 3 years shelf life (storage) presents acaricidal properties by indirect contact on adult females of T. urticae. The concentration at $1 \% \mathrm{w} / \mathrm{v}$ reached mortalities higher than $50 \%$ after $24 \mathrm{~h}$ of exposition. The other concentrations reached those values after $72 \mathrm{~h}$ of exposition. 
On the other hand, the essential oil of A. deserticola of 6 years shelf life does not present acaricidal properties because none of the tested concentrations reach mortalities higher than $50 \%$. The concentration at $0.7 \% \mathrm{w} / \mathrm{v}$ reached $50 \%$ of mortality after $72 \mathrm{~h}$ of exposition, without significant differences with the water control.

In relation to repellency, the concentration at $0.7 \% \mathrm{w} / \mathrm{v}$ of the essential oil of $A$. deserticola registered activity on $T$. urticae females, registering significant differences between the treated and untreated zone. After $24 \mathrm{~h}$ of exposition a $98 \%$ of individuals in the untreated area was registered, and over time this value decreases until $92 \%$ showing the repellent property of $A$. deserticola oil.

With respect to oviposition, the females of T. urticae present differences in the number of eggs laid when were exposed to formulations of 3 and 6 years shelf life. The essential oil of A. deserticola of 3 years shelf life maintains its acaricidal properties, presenting adult mortality over $50 \%$ and significantly affecting the oviposition of females.

\section{Literature Cited}

\section{Abbott, W.S.}

1925. A method of computing the effectiveness of an insecticide. J. Econ. Entomol., 18: 265-267.

Auger, P.; Migneon, P.; Ueckermann, E.A.; Tiedt, L.; Navajas, M. 2013. Evidence for synonymy between Tetranychus urticae and Tetranychus cinnabarinus (Acari, Prostigmata, Tetranychidae): review and new data. Acarologia, 53: 383-415.

Balasubramanian, A.V.; Arumugasamy, S.; Vijayalakshmi, K.; Subhashini, S.

2008. Plant products as biopesticides: building on traditional knowledge of Vrkshayurveda: Traditional Indian Plant Science. In $16^{\text {th }}$ IFOAM Organic World Congress 2008. Modena, Italy, 16-20 June.

Benites, J.; Tello, V.; Flores, N.; Tapia, D.; Ríos, D.; BucCalderon, $\mathrm{P}$.

2014. Acantholippia deserticola essential oil as a natural pesticide against agricultural plagues woolly whitefly [Aleurothrixus floccosus (Maskell)], Chilean false red mite (Brevipalpus chilensis Baker) and two-spotted mite (Tetranychus urticae Koch). B Latinoam Caribe P., 113 (3): 297-304.

Castiglioni, E.; Vendramim, J.D.; Tamai, M.A.

2002. Evaluación del efecto tóxico de extractos acuosos y derivados de meliáceas sobre Tetranychus urticae (Koch) (Acari: Tetranychidae). Agrociencia, 6 (2): 75-82.

Chiasson, H.; Bélanger, A.; Bostanian, N.; Vincent, Ch.; Poliquin, A.

2001. Acaricidal properties of Artemisia absinthium and Tanacetum vulgare (Asteraceae) essential oils obtained by three methods of extraction. J. Econ. Entomol., 94 (1): 167-171.

Darçın, E.S.; Darçın, M.

2017. Health effects of agricultural pesticides. Biomed Res, Special Issue: S13-S17.

Demaeght, P.; Dermauw, W.; Tsakireli, D.; Khajehali, J.; Nauen, R.; Tirry, L.

2013. Molecular analysis of resistance to acaricidal spirocyclic tetronic acids in Tetranychus urticae: CYP392E10 metabolizes spirodiclofen, but not its corresponding enol. Insect Biochem. Mol. Biol., 43 (6): 544-554.

Guo, X.; Shang, X.; Li, B.; Zhou, X.Z.; Wen, H,; Zhang, J. 2017. Acaricidal activities of the essential oil from Rhododendron nivale Hook. f. and its main compund, $\delta$-cadinene against Psoroptes cuniculi. Vet, Parasitol, 236: 51-54.
Harder, M.J.; Tello, V.E.; Giliomee, J.H.

2014. The acaricidal effect of ethanolic extracts of Chenopodium quinoa Willd. on Tetranychus urticae Koch (Acari: Tetranychidae). Afr Entomol, 24 (1): 50-60.

Immaraju, J.A.

1998. The commercial use of azadirachtin and its integration into viable pest control programmes. Pestic. Sci., 54: 285-289.

Jadev, N.; Gowen, S.R.; Inam-ul-Haq, M.; Abdullah, K.; Shahina, F.

2006. Systemic and persistent effect of neem (Azadirachta indica) formulations against root-knot nematodes, Meloidogune javanica and their storage life. Crop Prot., 26: 911-916.

Jallow, M.F.A.; Awadh, D.G.; Albaho, M.S.; Devi, V.Y.;

Thomas, B.M.

2017. Pesticide Knowledge and Safety Practices among Farm Workers in Kuwait: Results of a Survey. Int. J. Environ. Res. Public Health, 14 (340): 1-15.

Klein, C.; Waterhouse, D.F.

2000. The distribution and importance of arthropods associated with agriculture and forestry in Chile (Distribución e importancia de los artrópodos asociados a la agricultura y silvicultura en Chile). Ed. ACIAR Monograph 68. Canberra, Australia. $234 \mathrm{p}$.

Lu, W.; Wang, M.; Xu, Z.; Shen, G.; Wei, P.; Li, M.

2017. Adaptation of acaricide stress facilitates Tetranychus urticae expanding against Tetranychus cinnabarinus in China. Ecol. Evol. 7: 1233-1249.

Mithöfer, A.; Boland, W.

2012. Plant Defense Against Herbivores: Chemical Aspects. Annu. Rev. Plan.t Biol., 63: 431-450.

Morales, G.; Paredes, A.; Sierra, P.; Loyola, L.

2008. Antioxidant activity of $50 \%$ aqueous - ethanol extract from Acantholippia deserticola. Biol. Res., 41: 151-155.

Olsen, R.W.

2006. Picrotoxin-like channel blockers of GABAA receptors. Proc. Natl. Acad.Sci., 103 (16): 6081-6082.

Peralta, O.; Tello, V.

2011. Tabla de vida de Tetranychus cinnabarinus (Acari: Tetranychudae) sobre tres variedades de melón, Cucumis melo. Rev. Colomb. Entomol., 37 (1): 21-26.

Rojo, L.; Benites, J.; Rodríguez, A.; Venancio, F.; Ramalho,

L.; Teixeira, A.; Feio, S.; do, M.; Costa, C.

2006. Compostion and antimicrobial screening of the esencial oil of Acantholippia deserticola (Phil. ex F.phil) Moldenke. J. Essent. Oil. Res., 18 (6): 1-3. 
Sampietro, D.A.; Lizarraga, E.F.; Ibatayev, Z.A.; Omarova, A.B.; Suleimen, Y.M.; Catalán, C.A.N

2016. Chemical composition and antimicrobial activity of essential oils from Acantholippia deserticola, Artemisia proceriformis, Achillea micrantha and Libanotis buchtormensis against phytopathogenic bacteria and fungi. Nat. Prod. Res., 30 (17): 1950-1955.

Tabari, M.A.; Youssefi, M.R.; Benelli, G.

2017. Eco-friendly control of the poultry red mite, Dermanyssus gallinae (Dermanyssidae), using the $\alpha$-thujone-rich essential oil of Artemisia sieberi (Asteraceae): toxic and repellent potential. Parasitol. Res., 116 (5): 1545-1551.
Tello, V.; Siulan, J.; Vargas, R.

2014. Estudio preliminar del efecto acaricida de seis extractos metanólicos sobre la arañita bimaculada, Tetranychus urticae Koch. IDESIA, 32 (2): 37-45.

Ximénez-Embún, M.; Castañera, P.; Ortego, F.

2017. Drought stress in tomato increases the performance of adapted and non-adapted strains of Tetranychus urticae. J Insect Physiol 96: 73-81.

Zarria, K.; Gajardo, S.; Benites, J.; López, J.; Rojas, M.

2010. Formulación y evaluación de la estabilidad de una serie de vehículos, para el desarrollo de un biopesticida a base de aceite esencial de Acantholippia deserticola. BIOFARBO, 18 (2): 20-30. 
